\title{
A PROFETISA QUE AMAVA BRUCE LEE: ORIENTE E OCIDENTE NA PERSPECTIVA DE PERSÉPOLIS
}

Célia Tolentino e Luana Hordones Chaves

"Tutte le storie particolari vivono solo nel quadro della storia mondiale" (GRamsci, Quaderni del Carcere)

Duas semanas antes da realização das eleições constituintes da Tunísia, em 07 de outubro de 2011, um canal privado de televisão projetou o filme de animação Persépolis, de Marjane Satrapi e Vincent Paronnaud, em dialeto tunisiano. Dois dias depois, cerca de 200 manifestantes salafistas marcharam em direção à sede da TV, em Tunis, armados com paus e pedras e dispostos a destruí-la contra o que definiram como profunda ofensa religiosa. Esse grupo, minoria radical islâmica na Tunísia, acusava o filme de blasfêmia por conter imagens em que há a representação de Deus, o que é rigorosamente proibido pela religião. A partir desse episódio, os protestos se alargaram por todo o país, inclusive nas universidades, provocando preocupação na Europa em relação ao caráter das transformações que pareciam vir no rastro da chamada Primavera Árabe. Como consequência, o diretor desta rede de TV, Nabil Karoui, foi denunciado sob 
a acusação de "violar valores sagrados e perturbar a ordem pública" e o seu julgamento motivou um acirrado debate entre grupos muçulmanos moderados e conservadores na Tunísia, evidenciando o caráter das forças políticas em disputa. As principais questões em causa: os princípios fundamentais do Islã, a liberdade de expressão e a inclusão ou não da sharia ${ }^{1}$ no texto da nova Constituição.

O julgamento de Nabil Karoui ocorreu em 19 de abril de 2012, com forte presença militar separando os dois grupos manifestantes: de um lado, uma parcela da população muçulmana moderada e secularista e, de outro, a islâmica conservadora. A sentença do tribunal parece ter ficado a meio caminho, ou encontrado um meio termo: o diretor da TV foi multado em 2,4 mil dinares tunisianos (o que corresponde a 1,5 mil dólares) por transmitir um filme que "perturba a ordem pública e ameaça a moral adequada”. Outros dois funcionários, Nadia Jamal, chefe da organização que 250 trabalhou na dublagem do filme para dialeto tunisiano, e Alhadi Boughanim, responsável por programas de monitoração da estação televisiva, foram condenados a pagar a metade do referido valor à justiça. No entanto, a acusação mais grave, de "violar valores sagrados", foi descartada. Ainda assim, a condenação sob a justificativa de causar problemas à ordem pública e ofensa aos bons costumes em razão da exibição de uma obra como Persépolis parecem indicar algo sobre os rumos da nova ordem que aguarda o povo tunisiano que, há pouco mais de um ano, ocupava as ruas de Tunis em nome da liberdade.

Esta não foi a primeira vez que Persépolis foi contestado por fundamentalistas islâmicos. Quando foi escolhido para a Mostra de Cannes de 2007, o governo iraniano enviou uma nota de repúdio à sua exibição e, desde então,

\footnotetext{
${ }^{1}$ Lei islâmica que tem como referência a norma fundamental que se considera revelada por Deus, cujas fontes principais são o Alcorão (e por isso também chamada leis corânicas) e a coletânea dos Ditos e Atos do Profeta Maomé, a Sunna.
} 
Marjane Satrapi foi proibida de voltar ao seu país de origem. Esses dois episódios recentes parecem ser suficientes para legitimar a importância política do filme e justificar nosso interesse em discutir essa narrativa para, por meio dela, pensar aspectos da relação Oriente/Ocidente, além de revisitar, com a autora, a Revolução Iraniana que se tornou paradigmática para o mundo islâmico.

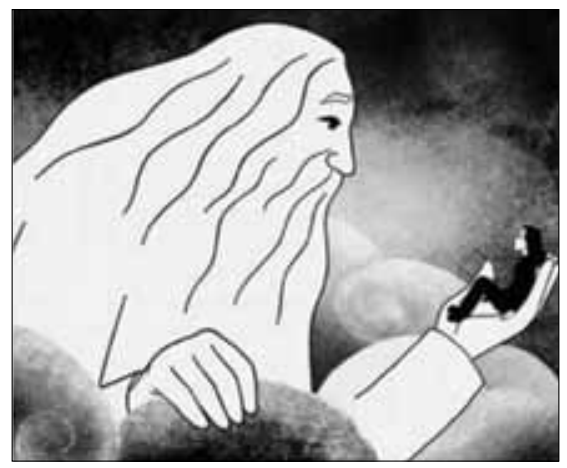

Apesar de contestada por grupos fundamentalistas e de, em contrapartida, fazer um imenso sucesso na Europa, a Teerã representada em Persépolis nem por isso se parece com aquela que conhecemos através dos veículos de comunicação que operam aquilo que Edward Said (1990) chamou de orientalismo. Segundo esse conceito, o ponto de vista ocidental, hegemônico política e ideologicamente, define o Oriente como um dado não apenas geográfico e culturalmente distinto, mas como um outro, dominado e subalterno. Quando escapa a esse enfoque, o ponto de vista ocidental o percebe segundo a lógica da exterioridade, como o exótico, o diverso. Como observa Said, o que muitas vezes se toma por verdade são apenas representações constituídas a partir de visões específicas, de desvios e de interesses, uma vez que a ação do orientalista passa pela escolha do que narra e pelo uso da linguagem com a qual narra, isto é, uma linguagem inteligível ocidentalmente, comprometendo, 
assim, sua narrativa e seu relato, já que a cultura representada concebe-se sob outros signos, outro sistema linguístico e outros códigos: “[...] se o Oriente pudesse representar a si mesmo, ele o faria; visto que ele não pode, a representação cumpre a tarefa para o Ocidente" (Said, 1990, p. 33). O cinema, inspirado por essa literatura Ocidental e etnocêntrica, acaba desenhando e reafirmando esse Oriente distante e imaginário.

O orientalismo refletiu-se também na representação do Islã, que passou a ser associado antes aos estereótipos e, hoje, aos atos políticos antiocidentais e ao terrorismo. Com o medo alastrado na sociedade ocidental, intensificam-se cada vez mais as representações próprias da ação orientalista, pegando carona na histórica visão do Islã como um sistema fechado e excludente, representado a partir de uma série de reduções e eliminações, conforme observa Said (1990). O autor considera ainda relevante o fato de que a palavra "islã" 252 seja usada para significar ao mesmo tempo uma sociedade, uma religião, uma realidade e um protótipo. Nesse sentido, comenta a noção de que "[...] as sociedades do islã ou do Oriente Médio são totalmente 'políticas', um adjetivo que tem a intenção de ser uma reprovação ao islã por não ser 'liberal', por não ser capaz de separar (como 'nós' somos) a política da cultura” (Said, 1990, p. 304).

Ao abordarmos o filme Persépolis podemos supor que estamos nos antípodas desse tipo de interpretação por se tratar de uma obra produzida por uma cidadã de origem iraniana, alfabetizada em idioma persa (além do francês) e oriunda de uma família profundamente enraizada, segundo narra, na cultura e na política daquele país. Desse modo, podemos supor uma visão, no mínimo, descolada dos problemas mais recorrentes do orientalismo quando, partindo das suas memórias, nos expõe os anos de intensa transformação política e cultural depois da queda do xá Reza Pahlevi e as alterações na vida cotidiana de seu grupo social - uma 
elite esquerdista e ocidentalizada pelos padrões locais, cujo projeto político acaba estrangulado pelo processo revolucionário. Relatando a difícil tarefa de crescer em tempos de guerra, sob graves conflitos sociais internos, traduz com um interessante distanciamento crítico a sensação de ser estrangeira tanto em sua casa quanto na Europa, para onde partiria num autoexílio preventivo. E é este olhar em perspectiva que nos interessa reter, pois, considerando que estamos no domínio da representação artística que não se origina no ocidente, podemos supor algo de revelador nesse discurso em primeira pessoa em relação ao que Said chama de orientalismo, assim como o que identificamos como uma espécie de seu "espelho", um possível ocidentalismo. Ambas as questões, em tese, seriam propostas nessa narrativa com conhecimento de causa, visto que Persépolis traz para o centro dessa antinomia a concretude de uma biografia que, observada sob uma dimensão política, acaba por mostrar aquilo que acima apontamos com Gramsci: toda história privada está perpassada inevitavelmente pela história universal.

Ao contrário do que propõem os orientalistas, seu país não aparece preso no tempo e no espaço, mas perpassado por elementos dos dois polos culturais mundiais, o que nos leva a sugerir que Marjane Satrapi é a narradora no "fio da navalha", seduzida em um primeiro momento pelo "ocidente ocidentalizado", para usar a ideia de Said às avessas, e crítica acerba das mazelas do seu próprio mundo, até experimentar o que há de trágico e belo, de sedução e engano em ambas as formas de política e cultura, de modo a traduzir artisticamente este ponto de vista histórico e crítico.

Persépolis relata como a geração de Satrapi viveu a Revolução de 1979 e, posteriormente, o governo de Khomeini, sem se deter, todavia, a descrever o mundo muçulmano e sua crença com olhar estranhado ou condescendente, outra "praga menor" do orientalismo, segundo Said (1990). A condescendência, observa o autor, gera a mitificação e a falsa repre- 
sentação do islamismo pelos povos ocidentais. Os vencedores da revolução são seus inimigos internos, observa Satrapi no discurso e na representação, suas teses e imposições religiosas para a vida cotidiana são consideradas retrógradas pela elite da qual faz parte, mas também por uma parcela da população religiosa e não fundamentalista. Implacável em suas críticas, a si e àqueles que a circundam, a narradora trata dos temas trágicos da perseguição, prisão e morte sem cair no vitimismo ou no dramalhão piegas que caracterizam certos filmes, que transferem os problemas políticos para o campo moral religioso, evocando a piedade do espectador.

Nesse sentido, o tom predominante em Persépolis é o da autoironia, pois ao mesmo tempo que a protagonista questiona o que vê no seu presente europeu, faz autocrítica do visto e vivido no Irã da sua infância e idade adulta. Plasmando na forma essa perspectiva, a cena inicial é indicativa desse recurso facilmente compreensível: tudo aqui254 lo que o olhar narrativo critica aparece exagerado, deformado ou avolumado. Exemplo disso são as representações da patrulha feminina religiosa e fundamentalista iraniana, cujas figuras lembram a perspectiva distorcida do quadro $O$ Grito, de Edward Munch, como assinalou alguém da crítica jornalística italiana, assim como das freiras em Viena, vistas de baixo para cima como três assustadores vultos escuros; ou na mais simples tradução da falta de atrativo físico do ex-namorado, sua primeira decepção amorosa relevante. $\mathrm{O}$ oposto também se faz evidenciar de maneira inequívoca: as pessoas queridas recebem traços sutis, alguma riqueza de detalhes e as cores predominantemente brancas, ao contrário do padrão escuro reservado aos desafetos. Deus, o pomo da discórdia para os salafistas tunisianos, traduzido como um velho de barbas e cabelos brancos, aparece com uma silhueta diáfana, de contornos sutis, traços semelhantes aos que "retratam" Karl Marx e o revolucionário e amado Tio Anuch. A avó materna também comparece desenhada com 
especial afeição, sugerindo que essa mulher seria o exemplo de feminilidade e força, de doçura e vigor, que representaria, segundo se deduz, a melhor herança de sua identidade de mulher iraniana.

Segundo conta Satrapi, sua família alargada pertenceria à dinastia Qadjar, deposta em 1921, por um golpe orquestrado com apoio da Inglaterra, que colocaria no trono o militar Reza Pahlevi. Em 1941, também por pressões externas, o xá conspirador teria de renunciar em favor do seu filho, Mohammad Reza Pahlevi, que tinha ímpetos modernizantes e ocidentalizantes, amava as festas faraônicas e reprimia com mão de ferro toda e qualquer oposição ao seu governo, até ser deposto em 1979. Herdeiros de perdas políticas na história iraniana, a família vive com euforia a queda do xá, mas é obrigada a encarar com lucidez a nova situação de recrudescimento religioso como mais uma derrota histórica. Este é o aprendizado da pequena Marjane, o grande legado da sua avó e do seu tio pelo lado paterno, Anuch, prisioneiro por nove anos como comunista opositor do governo do xá e entusiasta da revolução que o eliminaria, pouco depois de libertado, como inimigo do Islã.

A história começa observando nossa narradora no Aeroporto Internacional de Paris. Em cores na tela, o desenho representa o ir e vir de pessoas, filas e o corre-corre de um salão de embarque. Olhando para o display que mostra o horário de partida para Teerã, ajusta o véu negro sobre a cabeça e se dá conta do gesto automático. Na cena seguinte, num dos banheiros do aeroporto, a imagem no espelho reflete o contraste entre ela, com suas roupas largas que lhe escondem as formas do corpo, e uma mulher que pinta os lábios de vermelho vivo.

De um lado, os signos de uma cultura religiosa e, do outro, a cultura ocidental moderna com seus signos de liberdade sexual: a mulher usa um vestido "colado", decotado, com uma vistosa fenda lateral que lhe mostra as per- 
nas. Segundo o ponto de vista da narradora, a mulher olha com desconfiança para seus trajes austeros. A contrapartida é que também ela parece desconfiar dessa figura, pois os traços exagerados sugerem excesso de ostentação tanto do corpo quanto da moda. Como se trata de espelho e reflexo, podemos pensar que não é gratuito esse contraponto relativo à imagem e às aparências, particularmente a feminina, pois no olhar da exuberante ocidental colhemos uma ponta de piedade, indicando que a narradora sabe como pensam as mulheres ocidentais sobre as mulheres árabes e traz essa forma de orientalismo para a cena inicial: seriam todas vítimas indefesas de um sistema fechado e machista e precisariam ser resgatadas politicamente ou, quando a perspectiva não é condescendente, seriam todas submissas e adeptas desse costume atrasado.

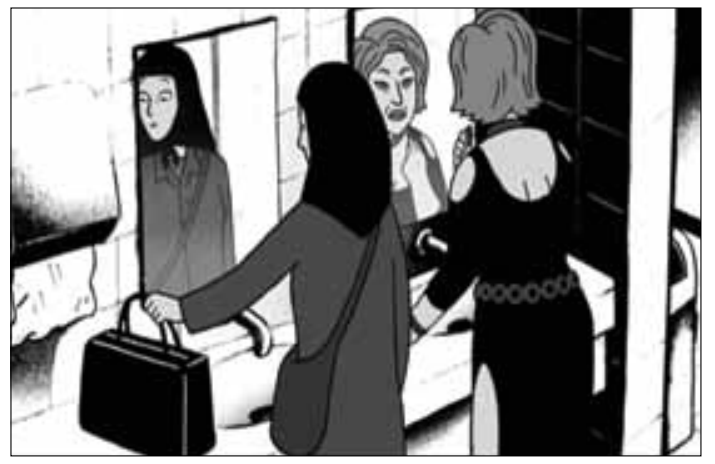

E nossa protagonista usará essa cena como mote para repensar o empreendimento ou não de uma viagem de retorno ao Irã. Diante da funcionária da companhia aérea que lhe pede o passaporte, parece hesitar. Até então, não sabemos o que essa jovem mulher pensa e seus trajes poderiam nos induzir a interpretá-la como adepta da cultura islâmica, como fez aquela com quem dividiu o espelho. É rápido e sutil o ponto de partida, mas é aqui que se estabelece o elemento-chave: o que se vê não é suficiente para compreender o outro. É desse 
entrecruzamento de culturas, não por acaso num aeroporto onde as silhuetas sugerem pessoas de todos os lugares e etnias, que vamos acompanhar sua história pregressa. Enquanto aguarda o embarque, ou decide se embarca ou não, nossa narradora rememora e nos diz quem é, porque está ali e porque se veste diferentemente dos padrões ocidentais.

É então que entram em cena os traços em preto e branco e bidimensionais (achatado e esquemático), comum na linguagem dos quadrinhos para crianças que, à primeira vista, não denuncia a carga de dramaticidade que poderá adquirir com os muitos tons de cinza entre o preto e o branco (lembrando que, embora esta seja uma metáfora senso comum da relatividade, é importante dizer que nossa narradora, como demonstrará, sempre tomará partido e sua tenacidade é apresentada por ela mesma como elemento fundamental da sua sobrevivência naqueles tempos de exceção). Com uma franqueza que passa a impressão de sinceridade, também se distancia de certo modelo de narrador autobiográfico típico dos filmes comerciais que, sutilmente, acabam fazendo desaparecer a perspectiva de classe e grupo social em nome de um sujeito pretensamente universal.

\section{A profetisa que amava Bruce Lee e batatas fritas}

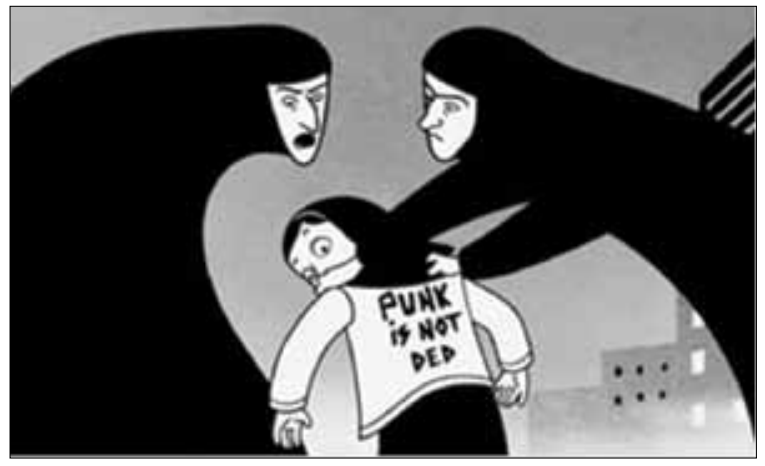


Eu me lembro que naquela época eu levava uma vida tranquila e sem problemas. Uma vida de menina! Adorava batatas fritas com ketchup, Bruce Lee era o meu herói, usava tênis Adidas e tinha duas grandes obsessões: poder raspar as pernas e virar a última profetisa da galáxia.

Assim começa o discurso de Marjane que, sentada no aeroporto, lembra-se do dia em que sua prima chegava de Paris à capital iraniana, em 1978. Nesse período, sob o regime do xá, o Irã investia na modernização e abertura em direção à economia ocidental e Marjane tinha nove anos. A sala do apartamento que festeja a chegada da prima viajante difere da costumeira ideia que temos sobre as casas de um país árabe. Todos se vestem à maneira ocidental, exceto Marjane com seu $\mathrm{Yi} \mathrm{Fu}$, o "uniforme" das artes marciais de Bruce Lee. Na cena seguinte, a menina lê para sua avó suas decisões como futura profetisa. Sua quinta proposição diz que 258 nenhum velho poderia sofrer mais. Sua avó então a interroga: "como vai fazer para que os velhos não sofram mais?" Ela responde: "Simples. Será proibido".

Esse pequeno dado, ali colocado pelo olhar de Marjane adulta com a função de ressaltar a impetuosidade de Marjane criança - muito observado pelas análises que destacam esta como a qualidade que fez a protagonista sobreviver às diversas catástrofes políticas e/ou psíquicas que a perseguiram lá e cá - é relevante para indicar que a menina absorvia, à sua revelia, juntamente com os ícones do Ocidente, o forte caráter autoritário e repressivo da cultura que a cercava, e fazia sua leitura de mundo sob ambas as influências. Seu desejo de ser profetisa, mais que indicar um traço de caráter, acaba indicando também que a política do regime islâmico não teria vigorado se não fosse a sobrevivência de uma cultura religiosa mantida latente, apesar do projeto ocidentalizante do xá Pahlevi e sua ascendência. É proibido sofrer: um paradoxo no qual se inscreve a própria herança 
cultural da narradora, espremida entre os ensinamentos da família com perspectivas socialistas (que reverbera no seu o "terceiro mandamento" de que "todos os pobres terão direito a comer um frango por dia”), o regime despótico e persecutório do xá e a tradição religiosa segundo a qual os profetas são inspirados diretamente por Deus (a menina tem certeza de manter interlocuções secretas em primeira pessoa com o Todo-Poderoso). Não por outra razão, a avó, "retratada" de forma visivelmente amorosa ${ }^{2}$, lhe dá como resposta: "eu deveria ter imaginado!".

A cena seguinte é igualmente instrutiva para indicar a formação dos ânimos e do seu caráter. Um "grito de guerra" vindo das ruas invade a sala do apartamento interrompendo as especulações entre neta e avó: em passeata, uma multidão grita com força "abaixo o xá". Segundo recorda, seu pai a toma nos braços e observa que estavam vivendo um momento histórico. Nas palavras da avó, finalmente o xá se juntaria aos seus "colegas de Washington".

A ligação do xá com "Washington" se explica desde o golpe de 1953, que derrubou o primeiro-ministro nacionalista Mossadeq e recolocou o xá Mohammed Reza Pahlevi no poder, contando com a ação da CIA.

Daí em diante o xá Reza Pahlevi passou a governar como um ditador. Não foi apenas um golpe, foi uma mudança de regime [...] Doravante, o xá não somente reinaria, ele também governaria. O Irã deixava de ser uma "monarquia constitucional" (ao menos formalmente) no estilo inglês, com o xá nomeando o primeiro-ministro por indicação parlamentar, mas sem interferir no gabinete, e passava a ser uma ditadura monárquica com cobertura parlamentar,

\footnotetext{
${ }^{2}$ A avó, viúva de um ex-preso político, divorciada do primeiro matrimônio, partidária de uma cultura laica, traz algo de mundano para suas críticas recheadas de inteligente ironia e alguns palavrões, desmontando a leitura mais comum a propósito das mulheres árabes, como indicava a cena do aeroporto.
} 
de um parlamento esvaziado de conteúdo e poder. E assim seria pelo próximo quarto de século, com consequências extraordinárias e contradições insolúveis, que a revolução de 1979 traria definitivamente ao centro do palco da história (Coggiola, 2008, p. 41-2).

A partir de então, Reza Pahlevi suprimiu as liberdades políticas e, com as restrições impostas, a maioria do clero xiita permaneceu fora da arena política. Integrando o campo ocidental, nas décadas seguintes, o Irã projetou-se como potência regional sob os interesses dos Estados Unidos, o que foi possível também devido ao investimento em tecnologia militar de ponta vinda da produção bélica norte-americana. Nos anos de 1960, o xá impôs um projeto de modernização nos moldes ocidentais, o que ficou conhecido como Revolução Branca: a reforma agrária e a emancipação das mulheres promoveriam a industrialização e a 260 educação, a fim de inserir o Irã no mundo globalizado.

No entanto, tal processo acabou beneficiando uma pequena camada de burgueses e enriquecendo donos de terras, forçando milhões de camponeses a migrar para as cidades, aumentando a miséria urbana, superlotando as favelas e levando ainda à construção de sua imagem como "inimigo do Islã". Com medidas como a proibição do uso do véu pelas mulheres, a censura ao clero, um atentado contra uma escola religiosa, a retirada de uma lei constitucional que obrigava a todos os membros do Parlamento serem seguidores do Islã, a atuação repressiva da polícia política do regime - a Savak -, crescia tanto entre a população pobre quanto entre a intelectualidade nacionalista e antiocidental a oposição ao xá, segundo a pesquisa de Peter Demant (2008).

A fala da avó indica também que a família tinha motivos privados para desejar a deposição de Pahlevi: "O coitado do seu pai enfim será vingado!”, observa a progenitora à 
mãe de nossa protagonista. Mas a obstinada Marjane retruca: "Pessoalmente eu penso que amo o xá. Ele foi escolhido por Deus! Sem dúvida! Foi o próprio Deus que me disse. Ele e a minha professora também!"

Então, esta teria sido a deixa para sua longa iniciação política. Paciente e didaticamente, aspecto traduzido pela representação gráfica como um teatro de marionetes, seu pai lhe explicaria como o Pahlevi sênior tomara o poder, desconstruindo a ideia disseminada nas escolas de que o governante era representante direto de Deus. A figura da professora de religião - desde já mencionada - é, no decorrer da narrativa, uma marca muito presente dos conflitos entre sua educação familiar laica e a pedagogia escolar religiosa e dogmática que, além de redirecionada, seria aprofundada após a revolução.

Segundo a narrativa, os acontecimentos políticos se sucedem como uma avalanche e, à morte de um jovem pela polícia secreta, seguem mais protestos, reprimidos à bala. Vendo seus pais participarem nas ruas ativamente, Marjane absorve a excitação política que passa a fazer parte de suas brincadeiras, para o incômodo de toda a família, repetindo obsessivamente a palavra de ordem: “abaixo o xá! Abaixo o xá!” Esta pode ser considerada uma das cenas-chave da narrativa. Marjane é inserida nos acontecimentos e forçada a compreendê-los precocemente. Após a derrubada de Pahlevi, veria chegar à sala de casa os ex-presos políticos vinculados à oposição comunista, ouviria os relatos das torturas sofridas pelos amigos e parentes, que tinham amargado a prisão durante o regime do xá, descritos com euforia e sem economia de detalhes, de tal modo que o tema passa a fazer parte da sua vida cotidiana, inclusive das brincadeiras com outras crianças.

Com esse aprendizado, a pequena Marjane e outros amigos da mesma idade se propõem a torturar um colega de vizinhança, cujo pai teria integrado a polícia política do governo deposto, como forma de vingança. Narrado de forma divertida, o projeto dos vingadores da causa é abortado pela inter- 
venção vigorosa de sua mãe, mas não deixa de ser sugestivo do clima de conflito generalizado. Estimulada a esquecer o passado em nome do futuro, a menina procura Ramine, o filho do torturador, para avisá-lo de sua decisão de "perdoá-lo" pelos crimes de seu pai. E a resposta do garoto poderia ser indicativa do que estaria por vir, sugere esta que narra o fato com a distância de alguns anos: "meu pai não cometeu crimes, apenas eliminou os comunistas". Os comunistas, ou socialistas, ou ledores de Lênin e Marx como seu avô e seu tio, estavam entre os principais perseguidos da dinastia Pahlevi e, embora participassem ávida e esperançosamente na revolução de 1979, seriam considerados, em breve, inimigos do novo regime. Nas memórias de Marjane:

Durante os meses que se seguiram à partida do xá o país atravessou um período de euforia. Todos tinham sido revolucionários, todos haviam combatido o xá. A mancha no 262 rosto da nossa vizinha tinha milagrosamente se tornado um ferimento de guerra. Nossa professora, fervorosa admiradora do xá, nos mandou arrancar dos livros escolares as fotos da família real. Havia comícios políticos por todos os lugares, e os inimigos de ontem, agora eram heróis da nação.

E se a volta do ex-preso político Siamak, amigo da família, lhe causara profunda inveja da amiguinha Laleh, que se apresentava como filha de um verdadeiro herói, a chegada de tio Anuch viria salvar nossa protagonista desse "complexo de inferioridade" e, ao mesmo tempo, ensinar-lhe sobre o trágico custo do heroísmo na luta política. Tio Anuch, comunista ativo, perseguido e preso, traria à Marjane as lutas e as expectativas de uma geração que acreditava na tarefa histórica do proletariado em relação à construção do socialismo. Anuch teria estudado marxismo-leninismo na então União Soviética e rezava por esta cartilha fielmente, como sugere a narrativa quando nos mostra sua reação dian- 
te da tomada do poder pelo líder xiita, o Aiatolá Khomeini: "É normal. Toda revolução tem seu período de transição. Metade do país é analfabeta. Só o nacionalismo e a moral religiosa podem unir as pessoas. Tudo vai dar certo”.

Ainda diante das prisões dos amigos da família, o confiante tio Anuch repetiria sempre: "Tudo vai dar certo". A relação entre a oposição comunista e a religiosa vinha de longa data, e é o que reverbera nas esperanças de tio Anuch, narradas aqui como uma ingenuidade política. Mas os desdobramentos seriam outros. Apresentando-se como uma ameaça ao xá Pahlevi, Khomeini tinha sido preso e forçado a exilar-se na Turquia em 1964, o que fez aumentar os protestos dos clérigos e, por conseguinte, a repressão violenta da polícia política do governo que, de acordo com os religiosos, matou milhares de manifestantes naquele ano. A partir de então, a oposição ficaria dividida entre as vertentes comunistas e os religiosos, mas em pouco tempo quase a totalidade da população seria contrária ao regime do xá e não tardaria muito para que a revolução eclodisse.

Conforme comenta Demant (2008), apesar de um considerável crescimento da economia, a crise fez crescer a inflação, deixando mais de um milhão de pessoas desempregadas, levando à falência comerciantes, afetando a classe média e enriquecendo a restrita classe dominante - sobretudo a autocracia governante. Acompanhado da inflação, do êxodo rural, da escassez de moradia e infraestrutura, da especulação imobiliária e do abismo social e econômico cada vez maior entre as classes, veio o descontentamento com a corrupção, com o cenário faraônico em que vivia o governo e com a violenta repressão à população. Nesse contexto, uma guerrilha dos mujaheedeen começava a tomar corpo. Ações como a explosão da central elétrica de Teerã, assaltos a bancos, a execução de um militar norte-americano e do chefe da polícia iraniana, acabaria por aproximá-la da guerrilha fadayin, de declarada inspiração marxista. 
Coggiola (2008), em sua análise da revolução iraniana, destaca que as condições sociais eram degradantes nos fins da década de 1970 e o ressentimento da população se transformava em um movimento revolucionário de massas, como indica a fala do tio da nossa protagonista. Mas, enquanto a classe operária reagia com greves, nas mesquitas os sermões pregavam a uma grande parcela da população os perigos dos valores ocidentais, dos quais o xá seria partidário. A população mais pobre constituía o segmento mais religioso e o menos ocidentalizado do Irã, observa o autor, e os líderes xiitas compreenderam que seguindo os conselhos de uma teoria do "islamismo revolucionário", poderiam ter apoio desta juventude para fazer da religião a força mobilizadora para tomada do poder.

Privados de imprensa sob o regime do xá, os partidos políticos e entidades estudantis voltaram-se para as mesquitas. Estas eram o único fórum aberto e representavam uma possibilidade real de que muitas pessoas fossem mobiliza264 das. As palavras de ordem política proferidas pelos aiatolás obtiveram bastante repercussão e Khomeini se elegeria, em 1979, como líder da nação muçulmana. O líder xiita governaria provisoriamente o Irã, com o Conselho da Revolução Islâmica, indicando o rumo a ser seguido para a proclamação da "República Islâmica". Entretanto, em 1980, ditou-se uma nova Constituição que, de teor teocrático, adotava a sharia como base das leis jurídicas do país.

E assim, o otimista tio Anuch, que acreditava que tudo ia dar certo para que a revolução caminhasse para o socialismo, acaba condenado à morte sob acusação de espionagem para a URSS, episódio tratado com pathos digno de uma tragédia. $\mathrm{O}$ heroico e amado tio, pouco antes de ser morto pelos revolucionários, escolhe a pequena Marjane como a última e única visita na, assim descrita, horrenda prisão destinada aos inimigos da causa. E na sua despedida lhe transmite o legado de manter viva a memória histórica da família. A narrativa fílmica mantém o foco na perspectiva da 
criança e sua profunda consternação é traduzida pela sensação de ser tragada pela espiral dos acontecimentos. Nas águas escuras da desolação, navegam os cisnes brancos feitos com miolo de pão pelo prisioneiro e condenado Anuch. Deus intervém para consolá-la e é expulso aos berros nesse pesadelo que parece ser o maior de sua vida, até que a voz dos pais a acorde e desmonte tal presságio: um bombardeio põe toda a família em risco e o porão, tão escuro quanto o quadro apenas descrito, passa a ser o lugar da sobrevivência física quando as sirenes tocam. Na voz da protagonista:

Um ano após a revolução, o Iraque atacou o Irã. Saddam se aproveitou da vulnerabilidade do país para atacar. A revolução e o massacre do Exército nos enfraqueceram terrivelmente. Em nome da luta contra o inimigo externo, o Estado iraniano exterminou o inimigo interno, isto é, os antigos oponentes ao regime do xá. As prisões e as execuções viraram moeda corrente. Todos tinham medo. O novo governo aproveitou para instaurar leis mais repressivas. Em dois anos, nosso cotidiano mudou totalmente e nós também.

A cena seguinte apresenta Marjane juntamente com outras meninas na escola - agora com classes separadas por gênero -, todas cobertas pelo véu e batendo no peito com a mão direita. Através de um alto-falante, palavras de ordem reclamam fidelidade ao regime dos aiatolás e submissão, em respeito àqueles que morriam na guerra, agora mártires e não mais heróis nacionais:

O véu é o sinônimo da liberdade. Uma mulher digna se protege do olhar do homem. A que se mostra está em pecado e arderá nas chamas do inferno. Nossos soldados morrem todos os dias nas fronteiras para salvar o nosso querido país da indecência. 
E, observará Marjane, morriam aos milhares, sobretudo os mais pobres, recrutados no seio das famílias proletárias religiosas, como a da empregada de sua casa, a cujo filho prometiam a "chave do céu" para que se tornasse um combatente.

Enquanto isso, driblando a censura e a vigilância, famílias como a de Satrapi decidiam ignorar o novo projeto cultural e político do governo islâmico "tentando levar uma vida normal", como ela diz. Na escola, enquanto a professora repete os mandamentos religiosos, as meninas de sua classe social e escolar trocam informações sobre suas aquisições proibidas, os discos de música pop e rock. As festas clandestinas são regadas a álcool e jogos de cartas e, por um tempo, uma parcela das mulheres se recusa ao uso público do véu.

Mas um episódio aparentemente pessoal dá a dimensão de que a situação recrudesceria: sua mãe, na saída de um supermercado, é agressivamente repreendida por um dos "guardiões" da revolução sob o argumento de que mulhe266 res descobertas mereciam ser estupradas no meio da rua. A partir disso, vários são os exemplos de choque entre a lei e as tentativas de burlá-la, algumas cômicas, outras trágicas, como a morte do tio Taher por falta de recursos no hospital apinhado de feridos de guerra. Nesses momentos, a narrativa faz questão de evidenciar o vezo de classe de uma parte da elite que, mais que não aceitar o propósito do governo islâmico, o vê como obra dos desqualificados ex-trabalhadores braçais. Também dá ideia de que, da parte desses sujeitos, haveria algo de ressentimento, para além do anticomunismo ferrenho. E este é um dos elementos interessantes do caráter crítico de Persépolis, pois sua narradora observa que se ela e seu grupo social foram perseguidos, as classes populares cederam milhões de vidas na guerra contra o Iraque e viram outras tantas mutiladas. Desse modo, se o governo fundamentalista se revelava autoritário, violento e persecutório para sua classe, era mortal para a população pobre e adepta ao governo religioso. 
Vale um parêntese para observar que nas páginas do HQ a exposição da agonia do tio Taher em meio aos muitos feridos de guerra ganha contornos mais dramáticos e o desabafo da protagonista: "eu sentia raiva e desconforto ao mesmo tempo". Assim como é importante a referência aos adolescentes pobres que foram aos campos de batalha em troca da chave do céu:

A chave do paraíso era para os pobres. Com a promessa de uma vida melhor, milhares de jovens com a chave pendurada no pescoço, explodiram nos campos minados. [...] Enquanto isso, eu fui à minha primeira festinha. Minha mãe não só me deixou ir como fez para mim uma blusa cheia de furos e um colar de correntes e pregos. Era a era do punk. Eu estava com um visual dos infernos (Satrapi, 2009, s/p).

A conjunção "enquanto isso" não deixa dúvidas da proporção comparativa entre o inferno de uns e de outros. Ou seja, mais de uma vez, a narrativa relativiza a tragédia pessoal fazendo esse tipo de contraponto, sutil na aparência, mas profundamente significativo para definir esta que fala.

Habituada ao debate no seio da própria família e em dia com as críticas ao regime pelos partidários do Estado laico, a narradora conta como em certo momento desafia mais uma professora de religião, quando esta afirma que no novo governo não teriam ocorrido prisões políticas. A contestação degenera em repreensão grave e, temendo que a filha de 13 anos fosse presa por oposição ao regime, os pais de Marjane decidem mandá-la para a Áustria, onde estudaria por alguns anos.

É nesse momento que se insere mais uma das partes emblemáticas dessa animação. Ela e sua família se definiam como ocidentalizados e eram legitimados por essa condição pelo regime ao qual se opunham. Mas a experiência da personagem no país ocidental é marcada por conflitos que não podemos deixar de analisar. Se a Europa do presente é 
sintomaticamente colorida, aquela conhecida compulsoriamente aos 13 anos se revela sombria na memória.

\section{"A Europa me esperava, mas não como eu imaginava"}

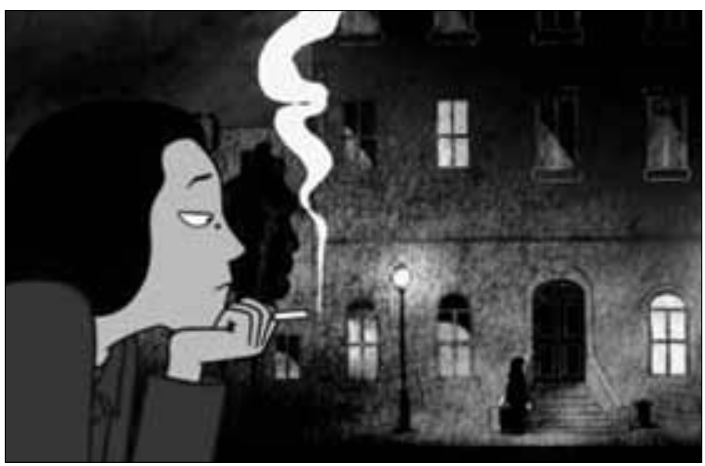

Em Viena, sua ideia de Ocidente logo se revela ocidentalista, voltando a fazer referência aqui ao conceito de Said às aves268 sas: "a Europa me esperava, mas não como eu imaginava”. As liberdades individuais, ou respeito ao indivíduo concreto propalado pela civilização ocidental moderna, não tarda a revelar-se como individualismo exacerbado, mas, nem por isso, sua condição de estrangeira passa despercebida e a discriminação, quase xenófoba, se faz sentir nas relações privadas e cotidianas. Ao mesmo tempo, a cultura da rebeldia sem causa e a futilidade de uma juventude imersa em grande bem-estar econômico e um manifesto mal-estar social se faz evidente para a recém-chegada que, fugindo de perseguições e mortes reais, se indispõe com a causa punk que, vista do seu país, parecia sinceramente rebelde.

Contando como acaba adotada pelo grupo de "marginais" do Liceu Francês de Viena, comenta a respeito do punk do grupo: "com Momo descobri a indiferença, o conceito do niilismo forçado e a vida alternativa vienense". Niilismo, apatia, frivolidade, consumismo, fascínio pela ideia de morte vão se constituindo como questões opostas ao 
cotidiano de guerra, perseguição, terror e carência de tudo que há pouco a narrativa trazia à baila em relação aos seus conterrâneos. Nesse contraponto, os problemas dos amigos de escola lhe parecem banalíssimos e superficiais: "Merda, Natal de novo. [...] Vou ter de ficar entediado com meus pais em Monte Carlo./ Monte Carlo não é nada, vou ter de visitar meu pai no Brasil. São umas 13 horas de voo”. E, em meio ao conflito da adaptação no país estranho, a narrativa expõe com seu bom humor característico a guerra interna da adolescência. Se em Teerã as guitarras do rock pesado do grupo Survivor, que por sua vez lembram metralhadoras, aliviava a ira e o medo da guerra real, na Áustria o punk rock injetava adrenalina no vazio cotidiano da nossa protagonista e seus abastados amigos de escola.

Vendo-se obrigada a morar em uma pensão de freiras católicas, rapidamente entra em choque com as rigorosas regras de comportamento e disciplina das religiosas. A sociedade laica lhe reservaria a pensão na casa de uma mulher solitária com seu mimadíssimo cão, tratado como membro da família, além do supermercado como um excelente lugar para disfarçar o tédio.

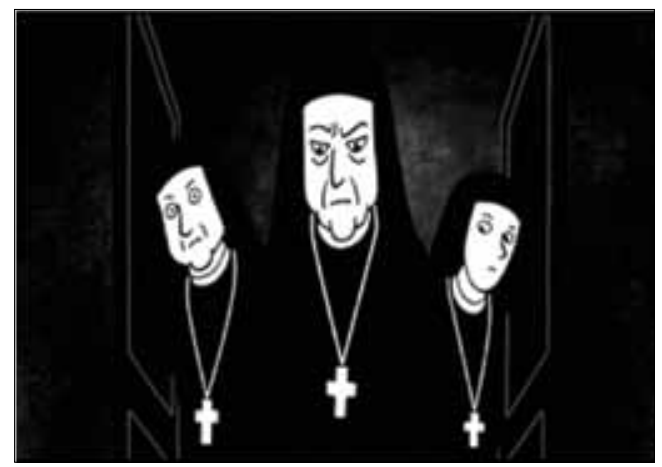

Nesse mundo de mal-estar moderno, vive sua primeira paixão adolescente, traduzida pelo traço rocambolesco como a estação do fascínio e dos clichês aprendidos com os 
filmes, os romances menores e as canções populares. Mas o seu traço característico retorna quando constata, rapidamente, que a realidade contraria a pieguice de Hollywood e alhures: sua origem era problemática para ser absorvida em uma família ocidental, e a mãe do namorado, assim como as colegas de escola, a fazem saber disso claramente, pondo a sua identidade em crise. E se o tradicionalismo no seu país preconizava que não se podia namorar nas ruas e que uma mulher não podia andar em público ao lado de um homem, caso este não fosse seu marido ou parente próximo, as relações afetivas e de amizade na Áustria seriam explícitas e livres, mas, em contrapartida, livres de qualquer compromisso com a vida do outro, como constataria a posteriori, quando experimenta a solidão individualista quase às últimas consequências depois de romper com o namorado, brigar com a dona da pensão e passar a morar nas ruas: "vivi uma revolução que me fez perder parte da minha família, sobrevivi a

270 uma guerra e uma banal história de amor quase me matou”. Tempos depois, já de volta ao Irã, diria ao futuro marido que defendia o Ocidente como a civilização da liberdade: "mas lá você pode morrer na rua que ninguém se importa”.

\section{Deus e Marx: a luta continua!}

Sem pátria, sem lugar, a meio caminho entre o comunitarismo opressivo, elevado à enésima potência em tempos de exceção no Irã, e a civilização ocidental sem coletivismo algum, sua volta para casa se traduz num potente conflito que mais uma vez põe sua vida em risco. Agora, não se tratava de absorver a rejeição de um namoradinho adolescente, mas encontrar-se com a própria identidade estilhaçada. A crença nas liberdades ocidentais se revelou ocidentalista, isto é, o paraíso das liberdades individuais, do consumo, do bem-estar econômico, da modernidade, tinha muito de ilusório e propagandístico do lado de cá e de idealizado pelo lado de lá. Mas também o mundo acanhado de um país em profunda crise econômica, destroça- 
do física e socialmente por oito anos de guerra, submetido à censura religiosa e política ainda mais ferrenha, ao familismo por razões de resistência ou cultura, lhe parecia insuportável depois do estágio europeu: "eu era uma estrangeira na Áustria e agora sou uma estrangeira no meu país".

E aqui vale o parêntese para observarmos algumas manifestações do que chamamos de ocidentalismo, na esteira do conceito de Said, explicitadas como tal ao longo da narrativa. Mais que decepcionada pelo estágio em Viena, quase derrotada pela indiferença individualista, assiste desconcertada ao interrogatório dos parentes que a recepcionam e que desejam saber sobre as maravilhas do paraíso ocidental, isto é, as boates, o consumo, a convivência com artistas famosos e as benesses da apregoada liberdade. Duas primas se escandalizam pelas suas vestimentas excessivamente simples, uma vez que, sob véu, se apresentam como mulheres sofisticadas, exageradamente maquiadas e em dia com as propagandas de moda. A contrapartida a este Ocidente idealizado é dada pela patrulha religiosa que define elementos da cultura ocidental como lixo e decadência: isso vale para o terno e gravata dos homens, para as músicas pop e rock, para o consumo de álcool, jogos de cartas e também à adesão ao projeto de sociedade e política não religiosas. Nesse confronto, observa a narrativa, uns demonizam os outros, e o que é proibido, de lado a lado, adquire uma importância exagerada. "Como, assim, você não frequentou as boates de Viena?”, pergunta a prima que, na sequência, se escandaliza ao saber que Marjane tivera uma vida sexual ativa.

Depois de meses, ainda deslocada e em profunda depressão, segundo conta, tenta suicídio ingerindo uma alta dose de barbitúricos. Em mais uma das expressões inteligentemente autoirônicas dessa animação, o ato quase extremo é narrado com muita leveza e de forma divertida, lembrando que esta que fala está dividida entre tradições, em tese, inconciliáveis: a cultura religiosa e a revolução 
socialista, ambas perpassando sua formação de forma indelével, indicando a relação entre a cultura circundante e a educação familiar ocidentalizada. O desafio é, como propõe, conciliar ambas e assumi-las como sua identidade, multifacetada já na origem. Improvável na história, propõe a conciliação no mundo dos desejos, isto é, dos sonhos: em meio ao delírio provocado pela ingestão dos antidepressivos, tem uma conversa séria com Deus e Marx, que vale a pena reproduzir. Em meio às nuvens, Deus observa impassível o horizonte até descobri-la flutuando às suas barbas:

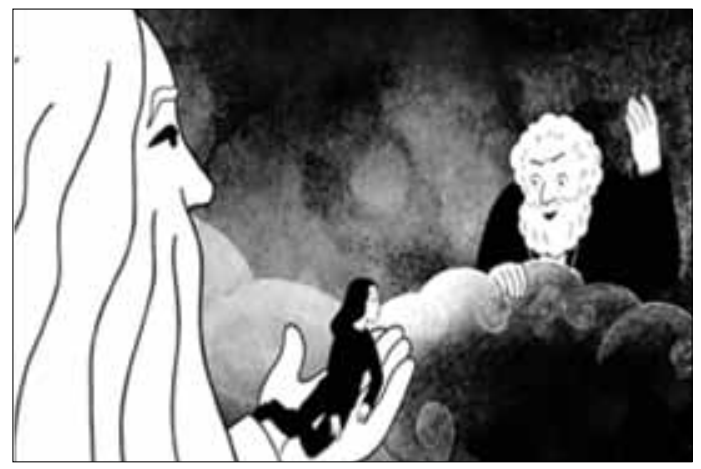

Deus: Filha, o que está fazendo por aqui?

Marjane: Estou morta.

Deus: Mas você não vê que sua hora ainda não chegou?

Marjane: É mesmo?

Deus: Você vai precisar se mexer um pouco.

Uma voz ao fundo: Sim, desta vez ele tem razão.

Marjane olha para trás e descobre ser de Marx: Você tem muitas coisas a fazer. Vamos, mexa-se!

Marx pisca o olho para Deus, que complementa: Vá e faça o que precisa ser feito. (Deus a manda de volta para a vida com um sopro, como reza a tradição judaico-cristã).

Marx: E não se esqueça: a luta continua!

Deus: É... a luta continua. 
Exorcizada da necessidade de resolver os conflitos gerados pela experiência ocidental e aqueles em casa própria, decide integrar-se e viver, na medida do possível, como todos os jovens da sua classe e da sua idade: cursando uma faculdade, contraindo um matrimônio para poder relacionar-se com um homem sem a opressão da polícia religiosa e fugindo da perseguição por pequenas atitudes rebeldes, às vezes deslealmente, como ela mesma relata. Mas, em algum momento, o retorno ao Ocidente seria inevitável e aconteceria sob o impacto da morte de um amigo após uma perseguição policial por causa de uma festa privada regada a rock e vinho.

Marjane, já em crise no casamento e contando com o apoio da avó, decide divorciar-se e se mudar para a França. É significativo que a narrativa se encerre com a fala da mãe na sua despedida, remetendo à problemática central, como um ciclo. O filme começa e termina com a ideia de proibição: nesse momento ela se vê proibida de voltar ao Irã, sob exigência de sua mãe. Uma resolução mais dura do que a simplificada ordem profética do início da narrativa, dando indícios de que alguns conflitos parecem não apresentar saídas senão na lógica da proibição. Tão no "fio da navalha" quanto a negociação entre a profecia e o comunismo, se encontra a vida de Marjane entre o Ocidente e a República Islâmica do Irã: a complexidade das intermediações entre dois mundos é evitada com a necessidade de escolha de um em detrimento do outro. Proibir é, de imediato, uma saída; no entanto, se, por um lado, parece evitar conflitos, por outro, impossibilita quaisquer chances desses mesmos conflitos se resolverem de fato. Se não fosse pela via inóspita da proibição e da condenação, a lição de Persépolis poderia ser, para a Tunísia de hoje, um impulso para o diálogo entre moderados secularistas e conservadores religiosos, afinal, "a luta continua".

Quando interditada, a convivência que produziria reflexões e intersecções apenas evidencia vazios e distanciamentos. E ei-la aqui, no aeroporto Charles de Gaulle a indagar-se sobre 
voltar ou não ao Irã. Decidindo que não, Marjane afirma para o taxista (e para nós) que a indaga sobre sua identidade: "sou iraniana". Ao encerrar a narrativa dessa maneira, sua origem vem a soar como nativa de uma ilha, de um dos arquipélagos políticos e culturais em evidência, tanto complexa como atual. A última fala da protagonista provoca inevitavelmente uma referência ao recente caso da proibição do véu às mulheres muçulmanas em lugares públicos na França. O país que lhe serviu de refúgio do radicalismo islâmico em outros tempos, hoje inviabiliza o diálogo entre o Ocidente e o mundo muçulmano fazendo uso da lógica da obrigatoriedade do véu no seu inverso. Desse modo, podemos concluir como Deus e Marx de Persépolis que, de fato, a luta precisa continuar.

\section{CÉLIA TOLENTINO}

é professora da Universidade Estadual Paulista Júlio de Mesquita Filho (FCC/UNESP).

\section{LUANA HORDONES CHAVES}

é doutoranda em Sociologia pela FAFICH/UFMG.

\section{Referências bibliográficas}

COGGIOLA, O. 2008. A Revolução iraniana. São Paulo: Ed. UNESP.

DEMANT, P. 2008. O mundo muçulmano. São Paulo: Contexto.

GRAMSCI, A. 1998. Quaderni dal cárcere. Torino: Einaudi.

SAID, E. 1990. Orientalismo: o oriente como invenção do ocidente. São Paulo: Companhia das Letras.

SATRAPI, M. 2009. Persépolis. São Paulo: Cia das Letras, Persepolis. 2007. Paris: L'Association. 


\section{A PROFETISA QUE AMAVA BRUCE LEE: ORIENTE E OCIDENTE NA PERSPECTIVA DE PERSÉPOLIS}

\section{CÉLIA TOLENTINO E LUANA HORDONES CHAVES}

Resumo: Neste artigo analisamos a obra Persépolis, longa metragem de animação que sintetiza os quatro volumes da obra homônima lançada na forma de história em quadrinhos na França, entre os anos de 2000 e 2003. Narrado pela autora Marjane Satrapi, conta os quinze anos sucessivos aos acontecimentos de 1979 no Irã, a partir de sua perspectiva pessoal. Pertencente a um grupo social de esquerda e ocidentalizado segundo o padrão iraniano, viu morrer as utopias deste segmento com a vitória da Revolução Islâmica. No entanto, num autoexílio em Viena, em plena adolescência, percebeu que a apregoada liberdade ocidental também cobrava o seu preço. Tomando a narrativa de Persépolis como um olhar literalmente em perspectiva, colocamos em debate aspectos políticos e sociais da relação Oriente/Ocidente, dialogando, particularmente, com a obra de Edward Said.

Palavras-chave: Persépolis; Tunísia; Revolução Islâmica Iraniana; Oriente/Ocidente; Cinema e Relações Internacionais.

\section{THE PROPHETESS WHO LOVED BRUCE LEE: EAST AND WEST IN PERSEPOLIS PERSPECTIVE}

Abstract: In this article it is examined the work Persepolis, animation movie which summarizes the four volumes of the homonymous work launched in the form of comics in France, between 2000 and 2003. Narrated by the author Marjane Satrapi, it portraits the 15 years following the events of 1979 in Iran, from her personal perspective. Belonging to a left-wing social group, westernized according to the Iranian standards, she saw its utopias die as the Islamic Revolution won. However, during an auto exile in Vienna in her teen ages, she realized that the vaunted western liberty also charged its price. 
Considering Persepolis narrative literally as a look into perspective, it is debated the political and social aspects of the relationship east / west in a particular relation with the work of Edward Said.

Keywords: Persepolis; Tunisia; Iranian Islamic Revolution, East / West, Film, Movie and International Relations. 